\title{
Research on the Conversion Coefficient for Measuring Radon Concentration in Water Based on Bubbling Method
}

\section{Tao Hu}

Hengyang Normal University https://orcid.org/0000-0001-9585-3345

\section{Zhongkai Fan}

Hengyang Normal University

Fen Lin

Hengyang Normal University

\section{Yixiang Mo}

Hengyang Normal University

\section{Ruomei Xie}

Hengyang Normal University

\section{Hongzhi Yuan}

Hengyang Normal University

\section{Luwei Wang}

Hengyang Normal University

Yanliang Tan ( $\nabla$ hytyl@163.com )

Hengyang Normal University

\section{Research Article}

Keywords: Radon concentration in water measurement, radiation measurement, RAD7, H2O accessory, bubbling method, conversion coefficient

Posted Date: November 8th, 2021

DOl: https://doi.org/10.21203/rs.3.rs-902931/v1

License: (c) (i) This work is licensed under a Creative Commons Attribution 4.0 International License. Read Full License 


\section{Research on the conversion coefficient for measuring radon concentration in water based on bubbling method}

Tao Hu, Zhongkai Fan, Fen Lin, Yixiang Mo, Ruomei Xie, Hongzhi Yuan, Luwei Wang, Yanliang Tan *

College of Physics and Electronic Engineering, Hengyang Normal University

Email: hytyl@163.com

Abstract: Radon is soluble in water, and the radon in drinking water is one of the sources of indoor radon. The China national standard for drinking water (GB5749-2006) indicates that the radon concentration in drinking water cannot be higher than $300 \mathrm{pCi} / \mathrm{L}$. The widely used method for measuring radon concentration in water is to use the RAD7 and the $\mathrm{H}_{2} \mathrm{O}$ accessory which provided by the Durridge Company for bubbling measurement. There are two kind sample bottles: $40 \mathrm{ml}$ and $250 \mathrm{ml}$; the measurement steps: bubbling for 5 minutes, and measuring for 20 minutes. For the $40 \mathrm{ml}$ sample volume the conversion coefficient is around 25 . For the $250 \mathrm{ml}$ sample volume the conversion coefficient is around 4. Since the price of the accessory is more than one thousand dollars, and the drying tube of the accessory is small, it needs to be replaced after each measurement which makes the operation is troublesome. We used a big drying tube to perform the radon concentration in water measurement. A new model for description the radon concentration in the gas circuit is proposed, and the conversion coefficient in any measurement condition is obtained. Any volume of sample bottle and drying tube can be used, selecting the suitable bubbling time and measuring time, the radon concentration in water can be obtained.

Keywords: Radon concentration in water measurement; radiation measurement; RAD7; $\mathrm{H}_{2} \mathrm{O}$ accessory; bubbling method; conversion coefficient 


\section{Introduction}

Radon (Rn-222) is a chemically inert and odorless radioactive gas from the uranium (U-238) decay chain (Tan et al. 2020). And its half-life is 3.8 days. It is one of the most important naturally occurring radioactive nuclides and contributes to more than $50 \%$ of the ionizing radiation dose of humans (UNSCEAR 2000). In addition, atmospheric particles containing Rn decay products are of high relevance to humans since they may be deposited in the respiratory tract, causing high radiation hazards (Eichler B et al. 2000). Radon is soluble in water, which allows radon to enter the house through groundwater aquifers and indoor pipelines. The radon gas in water is mainly derived from the decay and release of radium dissolved in water. It should be noted that around $1-2 \%$ of radon in the air comes from drinking water (USEPA 1991). The sanitary standard for drinking water (GB5749-2006) stipulates that the concentration of radon in drinking water cannot be higher than $300 \mathrm{pCi} / \mathrm{L}$. Despite being less of a health risk than its airborne counterpart, radon carried in water is often a major transportation mechanism leading to high airborne radon concentration (Welch LE. 1994). As a result of its noble gas configuration radon behaves biologically and chemically inert. Due to that property, it is applied as environmental tracer in hydrology, geochemistry, and oceanography for tracking of transport pathways in aquifers and surface water systems and for the quantification of admixture rates (Axel Schmidt et al. 2008). Especially for seismology, earthquakes and other similar geological activities like volcanic explosion will affect the concentration of radon in groundwater, which is usually measured for earthquake prediction (Igarashi G et al.1995. Pradeep Talwani et al. 1980. Liu et al. 1984).

Therefore, the measurement of radon concentration in water is a very meaningful work. Based on different purpose and requirement, the radon-in-water measurement methods and systems can be quite different. Commonly used methods are liquid scintillation counting (LSC) method, gamma spectrometry method and emanometric method, which are recommended by ISO 13164 (ISO 2013). The measuring method includes diffusion, degassing membrane method and the bubbling method. In 
bubbling method, the balance time of radon-in-water and radon-in-air concentration is shortened by increasing the contact area between water and air with bubbling probe (Wang et al. 2020). Therefore, this method has been widely used, and new measurement methods and equipment have been developed, such as an improved version of the ionization chamber, a series of equipment based on bubble chambers and RAD7 monitors (D Lane-Smith. 2001. H Dulaiova et al. 2005. Dimova et al. 2009. Stieglitz et al. 2010. Lee et al. 2014), as well as commercial instruments like RAD $\mathrm{H}_{2} \mathrm{O}$ (Malik et al. 2014), RAD AQUA and some other devices (Teng. 1980).

The widely used device for bubbling to measure radon concentration in water is to use the RAD7 and the $\mathrm{H}_{2} \mathrm{O}$ accessory which provided by the Durridge Company. For the $40 \mathrm{ml}$ sample volume the conversion coefficient is around 25 . For the $250 \mathrm{ml}$ sample volume the conversion coefficient is around 4 (https://durridge.com). Since the price of the accessory is more than one thousand dollars, and the drying tube of the accessory is small, it needs to be replaced after each measurement which makes the operation is troublesome. We used a big drying tube to perform the radon concentration in water measurement. A new model for description the radon concentration in the gas circuit is proposed, and the conversion coefficient in any measurement condition is obtained. Any volume of sample bottle and drying tube can be used, selecting the suitable bubbling time and measuring time, the radon concentration in water can be obtained.

\section{Theoretical Descriptions}

\section{Measurement process}

The water radon measurement device based on the bubbling method is shown in Fig.1. The method for measuring radon concentration in water by the above-mentioned bubbling method water includes such process as follows: 


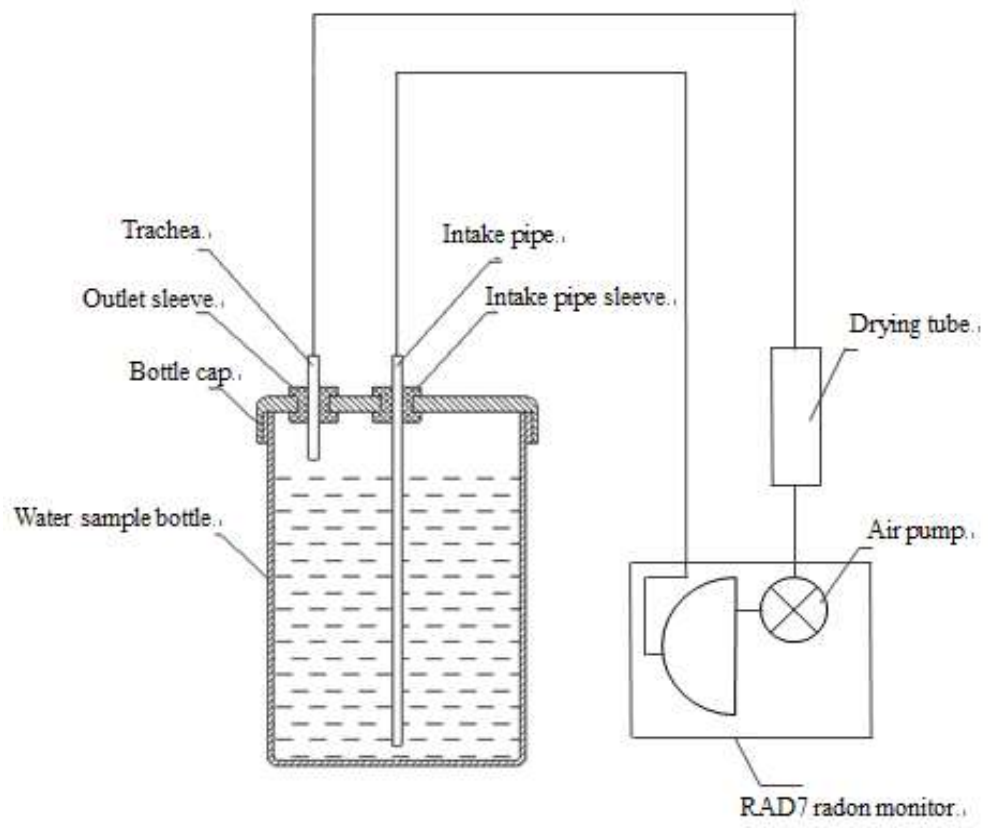

84

Fig.1 Water radon measurement device based on bubbling method

(1) Pour the water sample to be tested into the water sample measuring bottle and close the cap tightly. The air outlet of the inlet pipe of the water sample bottle is in the water sample to be tested and is close to the bottom of the water sample bottle, and the air inlet of the gas outlet pipe of the water sample bottle is located on the liquid surface of the water sample to be tested.

(2) Start the air pump and control the flow rate of the air pump to make air bubble into the water sample through the intake pipe of the water sample bottle. The generated bubbles will fully contact the water sample during the ascent process, and the radon in the water will enter the bubbles through the diffusion effect. At the same time, the radon in the water sample is carried out, and enters the drying tube through the air outlet pipe of the water sample bottle, and then passes through the air pump, and then enters the internal cell of theRAD7 radon monitor.

(3) After several periods of measurement, the water radon concentration can be obtained from the measurement value of RAD7.

Assuming that the initial radon concentration in water is $\mathrm{C}_{0}$, the initial concentration of radon and Po-218 in the air circuit of the device for measuring radon concentration in water by the bubbling method is 0 . Thus, the water sample measuring 
bottle was replaced with a bottle filled with charcoal before the experiment to adsorb the radon in the air loop. Using the pump of the RAD7, the air is continuously circulated in the loop, and the radon concentration in the loop will reduce until it drops to 0 .

\section{Calculation process}

Assuming the water radon concentration in the water sample measuring bottle is $\mathrm{C}_{1}(\mathrm{t})$, the radon concentration in the air circuit is $\mathrm{C}_{2}(\mathrm{t})$, and the Po-218 concentration in the internal cell of RAD7 is $\mathrm{C}_{3}(\mathrm{t})$.

Assuming that the radon concentration in the bubble has reached equilibrium with the radon in the water during the process from the inlet pipe of the water sample measuring bottle to the water surface, the following relationship exists between $C_{1}(t)$ and $\mathrm{C}_{2}(\mathrm{t})$ :

$$
\frac{d C_{1}(t)}{d t}=\frac{L\left[C_{2}(t)-X C_{1}(t)\right]}{V_{1}}
$$

where $V_{1}$ is the water sample volume; $\mathrm{L}$ is the flow rate of the pump. And $\mathrm{X}$ is the ratio of radon in air to radon in water at equilibrium. According to the reference (Weigel. 1978):

$$
K_{\text {w/air }}=\frac{C_{w}}{C_{\text {air }}}=f(T)=0.105+0.405 e^{-0.0502 T\left[{ }^{\circ} \mathrm{C}\right]}
$$

where $\mathrm{T}$ is the temperature of the water sample $\left({ }^{\circ} \mathrm{C}\right)$. So $X=\frac{C_{\text {air }}(t)}{C_{w}(t)}=\frac{1}{K_{w / a i r}}$, the value of $\mathrm{X}$ is related to temperature.

$$
\frac{d C_{2}(t)}{d t}=\frac{L\left[X C_{1}(t)-C_{2}(t)\right]}{V_{2}}
$$

where $\mathrm{V}_{2}$ is the volume of air circuit.

According the measurement principle of the RAD7, $\mathrm{C}_{2}(\mathrm{t})$ and $\mathrm{C}_{3}(\mathrm{t})$ have the following relationship (Tan et al. 2011. Tan et al. 2013):

$$
\frac{d C_{3}(t)}{d t}=\lambda_{P o} C_{2}(t)-\lambda_{P o} C_{3}(t)
$$

where $\lambda_{\mathrm{Po}}$ is the decay constant of Po-218. 


$$
\begin{aligned}
& C_{1}(t)=\frac{C_{0} V_{1}}{V_{1}+V_{2} X}+\frac{C_{0} V_{2} X e^{-t \frac{L V_{1}+L V_{2} X}{V_{1} V_{2}}}}{V_{1}+V_{2} X} \\
& C_{2}(t)=\frac{C_{0} V_{1} X}{V_{1}+V_{2} X}-\frac{C_{0} V_{1} X e^{-t \frac{L V_{1}+L V_{2} X}{V_{1} V_{2}}}}{V_{1}+V_{2} X} \\
& C_{3}(t)=\frac{C_{0} V_{1} X}{V_{1}+V_{2} X}-\frac{C_{0} L V_{1} X e^{-\lambda_{P o} t}}{L V_{1}+L V_{2} X-V_{1} V_{2} \lambda_{P o}}
\end{aligned}
$$

$$
+\frac{C_{0} V_{1}^{2} V_{2} X \lambda_{P o} e^{-t \frac{L V_{1}+L V_{2} X}{V_{1} V_{2}}}}{\left(V_{1}+V_{2} X\right)\left(L V_{1}+L V_{2} X-V_{1} V_{2} \lambda_{P o}\right)}
$$

137

Assuming the Sampling time is $t_{1}$, and the internal cell of the RAD7 radon monitor is applied with high voltage. Set the suitable sampling time, the radon concentration inside the device is evenly mixed. In the period of $t_{1} \sim t_{2}$, the reading of RAD7 is the Po-218 concentration (Tan et al. 2015). Assuming $m$ is the total Po-218 count of RAD7 in the measuring period of $t_{1} \sim t_{2}$ :

$$
\begin{aligned}
& m=\int_{t_{1}}^{t_{2}} C_{P o}(t) d t \\
& =\frac{C_{0} V_{2}^{2} X \lambda_{P o}\left(e^{-\frac{L+L X \frac{V_{2}}{V_{1}} t_{1}}{V_{2}}}-e^{-\frac{L+L X \frac{V_{2}}{V_{1}}}{V_{1}} t_{2}}\right)}{L^{2}\left(1+\frac{V_{2}}{V_{1}} X\right)^{2}\left(1+X \frac{V_{2}}{V_{1}}-\frac{V_{2} \lambda_{P o}}{L}\right)}-\frac{C_{0} X \times\left(t_{1}-t_{2}\right)}{1+X \frac{V_{2}}{V_{1}}}-\frac{C_{0} X\left(e^{-\lambda_{P o} t_{1}}-e^{-\lambda_{P o} t_{2}}\right)}{\lambda_{P_{o}}\left(1+X \frac{V_{2}}{V_{1}}-\frac{V_{2} \lambda_{P o}}{L}\right)}
\end{aligned}
$$

$\mathrm{n}$ is the average value measured by the RAD7 during $t_{1} \sim t_{2}$ :

$$
n=\frac{\int_{t 1}^{t 2} C_{P o}(t) d t}{t_{2}-t_{1}}=\frac{m}{t_{2}-t_{1}}
$$

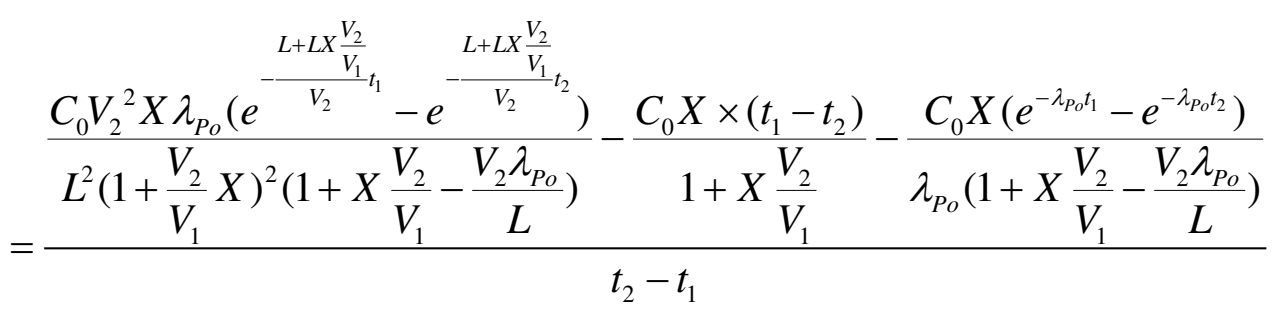

$\mathrm{k}$ is the conversion coefficient, and it is equal to the ratio of the initial concentration $\mathrm{C}_{0}$ of the radon in water to the average value measured by the RAD7 
within $t_{1} \sim t_{2}$ :

$$
\begin{aligned}
& k=\frac{C_{0}}{n}=\frac{C_{0} \times\left(t_{2}-t_{1}\right)}{m} \\
& =\frac{\left(t_{2}-t_{1}\right)}{\frac{X \lambda_{P o}\left(e^{-\frac{L+L X X V_{2}}{V_{2}} t_{1}}-e^{-\frac{L+L X V_{2}}{V_{2}} t_{2}}\right)}{\left(\frac{L}{V_{2}}\right)^{2}\left(1+\frac{V_{2}}{V_{1}} X\right)^{2}\left(1+X \frac{V_{2}}{V_{1}}-\frac{V_{2} \lambda_{P o}}{L}\right)}-\frac{X \times\left(t_{1}-t_{2}\right)}{1+X \frac{V_{2}}{V_{1}}}-\frac{X\left(e^{-\lambda_{P o} t_{1}}-e^{-\lambda_{P o} t_{2}}\right)}{\lambda_{P o}\left(1+X \frac{V_{2}}{V_{1}}-\frac{V_{2} \lambda_{P o}}{L}\right)}}
\end{aligned}
$$

144 simplified as:

147

$$
k \approx \frac{\left(t_{2}-t_{1}\right)}{\frac{X \lambda_{P o} e^{-\frac{L+L X \frac{V_{2}}{V_{1}}}{V_{2}} t_{1}}}{\left(\frac{L}{V_{2}}\right)^{2}\left(1+\frac{V_{2}}{V_{1}} X\right)^{2}\left(1+V_{2}\left(\frac{X}{V_{1}}-\frac{\lambda_{P o}}{L}\right)\right)}-\frac{X \times\left(t_{1}-t_{2}\right)}{1+X \frac{V_{2}}{V_{1}}}-\frac{X e^{-\lambda_{P o} t_{1}}}{\lambda_{P o}\left(1+V_{2}\left(\frac{X}{V_{1}}-\frac{\lambda_{P o}}{L}\right)\right)}}
$$

148

equation (11) can be simplified to:

151

$$
k \approx \frac{\left(t_{2}-t_{1}\right)}{\frac{X \lambda_{P o} e^{-\frac{L+L X \frac{V_{2}}{V_{2}}}{V_{2}} t_{1}}}{\left(\frac{L}{V_{2}}\right)^{2}\left(1+\frac{V_{2}}{V_{1}} X\right)^{3}}-\frac{X \times\left(t_{1}-t_{2}\right)}{1+X \frac{V_{2}}{V_{1}}}-\frac{X e^{-\lambda_{P o} t_{1}}}{\lambda_{P o}\left(1+X \frac{V_{2}}{V_{1}}\right)}}
$$




$$
k \approx \frac{\left(t_{2}-t_{1}\right)}{\frac{\lambda_{P o} e^{-\frac{L+L X \frac{V_{2}}{V_{1}}}{V_{2}} t_{1}}}{L^{2} \frac{V_{2}}{V_{1}^{3}} X^{2}}-\frac{\left(t_{1}-t_{2}\right)}{\frac{V_{2}}{V_{1}}}-\frac{e^{-\lambda_{P_{o} t_{1}}}}{\lambda_{P o}\left(\frac{V_{2}}{V_{1}}\right)}}
$$

If $L$ is large enough, $\frac{\lambda_{P o} e^{-\frac{L+L X \frac{V_{2}}{V_{1}}}{V_{2}}} t_{1}}{L^{2} \frac{V_{2}}{V_{1}^{3}} X^{2}}$ approaches 0 , and the equation (13) can be 156 simplified to:

$$
k \approx \frac{\left(t_{2}-t_{1}\right)}{\frac{\left(t_{2}-t_{1}\right)}{\frac{V_{2}}{V_{1}}}-\frac{e^{-\lambda_{P o} t_{1}}}{\lambda_{P o}\left(\frac{V_{2}}{V_{1}}\right)}}
$$

The decay constant of Po-218 is $0.228 \mathrm{~min}^{-1}$, when $t_{2}-t_{1}>>\frac{e^{-\lambda_{P_{0}} t_{1}}}{\lambda_{P_{o}}}$, the equation (14) can be simplified to:

$$
k \approx \frac{\left(t_{2}-t_{1}\right)}{\frac{\left(t_{2}-t_{1}\right)}{V_{2}}}=\frac{V_{2}}{V_{1}}
$$

For different sample bottle, assuming $k_{1}=\frac{V_{21}}{V_{11}}, k_{2}=\frac{V_{22}}{V_{12}}$, if $V_{21}=V_{22}$, then coefficient between $40 \mathrm{ml}$ and $250 \mathrm{ml}$ sample bottle is 25 to 4 , and it is consistent with the equation (15).

In summary, equation (10) can be used to calculate the radon concentration in the water sample. When the corresponding conditions are suitable, the water radon concentration can be calculated by equation (11) or (12) or (13) or (14) or (15). 


\begin{tabular}{ccccccc}
\hline $\begin{array}{c}\text { Experiment } \\
\text { No. }\end{array}$ & $\begin{array}{c}\text { Sample } \\
\text { bottle } \\
\text { volume }\end{array}$ & $\begin{array}{c}\text { Reading } \\
\left(\mathrm{Bq} / \mathrm{m}^{3}\right)\end{array}$ & $\begin{array}{c}20-25 \mathrm{~min} \\
\text { Reading } \\
\left(\mathrm{Bq} / \mathrm{m}^{3}\right)\end{array}$ & $\begin{array}{c}25-30 \mathrm{~min} \\
\text { Reading } \\
\left(\mathrm{Bq} / \mathrm{m}^{3}\right)\end{array}$ & $\begin{array}{c}30-35 \mathrm{~min} \\
\text { Reading } \\
\left(\mathrm{Bq} / \mathrm{m}^{3}\right)\end{array}$ & $\begin{array}{c}\text { 35-40min } \\
\text { Reading } \\
\left(\mathrm{Bq} / \mathrm{m}^{3}\right)\end{array}$ \\
\hline 1 & $200 \mathrm{ml}$ & $40 \pm 180$ & $110 \pm 220$ & $100 \pm 200$ & $100 \pm 200$ & $40 \pm 170$ \\
1 & $500 \mathrm{ml}$ & $180 \pm 290$ & $150 \pm 240$ & $260 \pm 280$ & $150 \pm 280$ & $220 \pm 270$ \\
2 & $200 \mathrm{ml}$ & $206 \pm 250$ & $34.2 \pm 165$ & $137 \pm 222$ & $137 \pm 222$ & $240 \pm 263$ \\
2 & $500 \mathrm{ml}$ & $309 \pm 286$ & $309 \pm 286$ & $446 \pm 326$ & $240 \pm 263$ & $343 \pm 296$ \\
3 & $200 \mathrm{ml}$ & $68.3 \pm 187$ & $68.3 \pm 187$ & $34.2 \pm 165$ & $68.3 \pm 187$ & $103 \pm 205$ \\
3 & $500 \mathrm{ml}$ & $205 \pm 249$ & $171 \pm 236$ & $34.2 \pm 165$ & $275 \pm 275$ & $171 \pm 236$
\end{tabular}

\section{Results and Discussion}

Three experiments are performed. $200 \mathrm{ml}$ and $500 \mathrm{ml}$ water sample bottle are used in these experiments. Take out a bucket of water from the lake and pour it into two kind water sample bottles in each experiment.

The volume of the gas circuit of the $200 \mathrm{ml}$ water sample bottle device is $1.467 \mathrm{~L}$, and the volume of the gas circuit of the $500 \mathrm{ml}$ water sample bottle device is $1.456 \mathrm{~L}$. The pump flow rate of RAD7 is $0.7 \mathrm{~L} / \mathrm{min}$. The setting of the RAD7 is: mode, sniff; cycle, 5minutes; recycle, 8 .

The pump works for 15 minutes, which can make the gas in the pipeline circulate 7 times, so that the gas in the pipeline is evenly mixed. The measurement is completed within 15-40min. Table 1 lists all the measurement data.
182 
Table 2 Radon concentration in water and the conversion coefficient

\begin{tabular}{ccccc}
\hline $\begin{array}{c}\text { Experiment } \\
\text { No. }\end{array}$ & $\begin{array}{c}\text { Sample } \\
\text { bottle } \\
\text { volume }\end{array}$ & $\begin{array}{c}\text { Conversion } \\
\text { coefficient(k) }\end{array}$ & $\begin{array}{c}\text { Measured average } \\
\text { radon } \\
\text { concentration } \pm 2 \sigma \\
\left(\mathrm{Bq} / \mathrm{m}^{3}\right)\end{array}$ & $\begin{array}{c}\text { Radon } \\
\text { concentration in } \\
\text { water } \pm 2 \sigma \\
\left(\mathrm{Bq} / \mathrm{m}^{3}\right)\end{array}$ \\
\hline 1 & $200 \mathrm{ml}$ & 7.63 & $78 \pm 66$ & $595 \pm 504$ \\
1 & $500 \mathrm{ml}$ & 3.18 & $192 \pm 85$ & $611 \pm 270$ \\
2 & $200 \mathrm{ml}$ & 7.63 & $151 \pm 141$ & $1152 \pm 1076$ \\
2 & $500 \mathrm{ml}$ & 3.18 & $329 \pm 134$ & $1046 \pm 426$ \\
3 & $200 \mathrm{ml}$ & 7.63 & $68 \pm 44$ & $519 \pm 336$ \\
3 & $500 \mathrm{ml}$ & 3.18 & $171 \pm 153$ & $544 \pm 487$
\end{tabular}

The results listed in Table 3 show that the radon concentrations in water in two kind bottles are similar in each experiment. The differences of the radon concentrations in water among the three experiments are caused by difference of the sampling time and location of the lake.

Assuming $\mathrm{C}_{0}$ is $600 \mathrm{~Bq} / \mathrm{m}^{3}$, Fig. 2 and 3 illustrate the concentration change $\mathrm{C}_{1}(\mathrm{t})$, $\mathrm{C}_{2}(\mathrm{t})$, and $\mathrm{C}_{3}(\mathrm{t})$ in the $200 \mathrm{ml}$ and $500 \mathrm{ml}$ sample bottle by equation (5), (6) and (7).

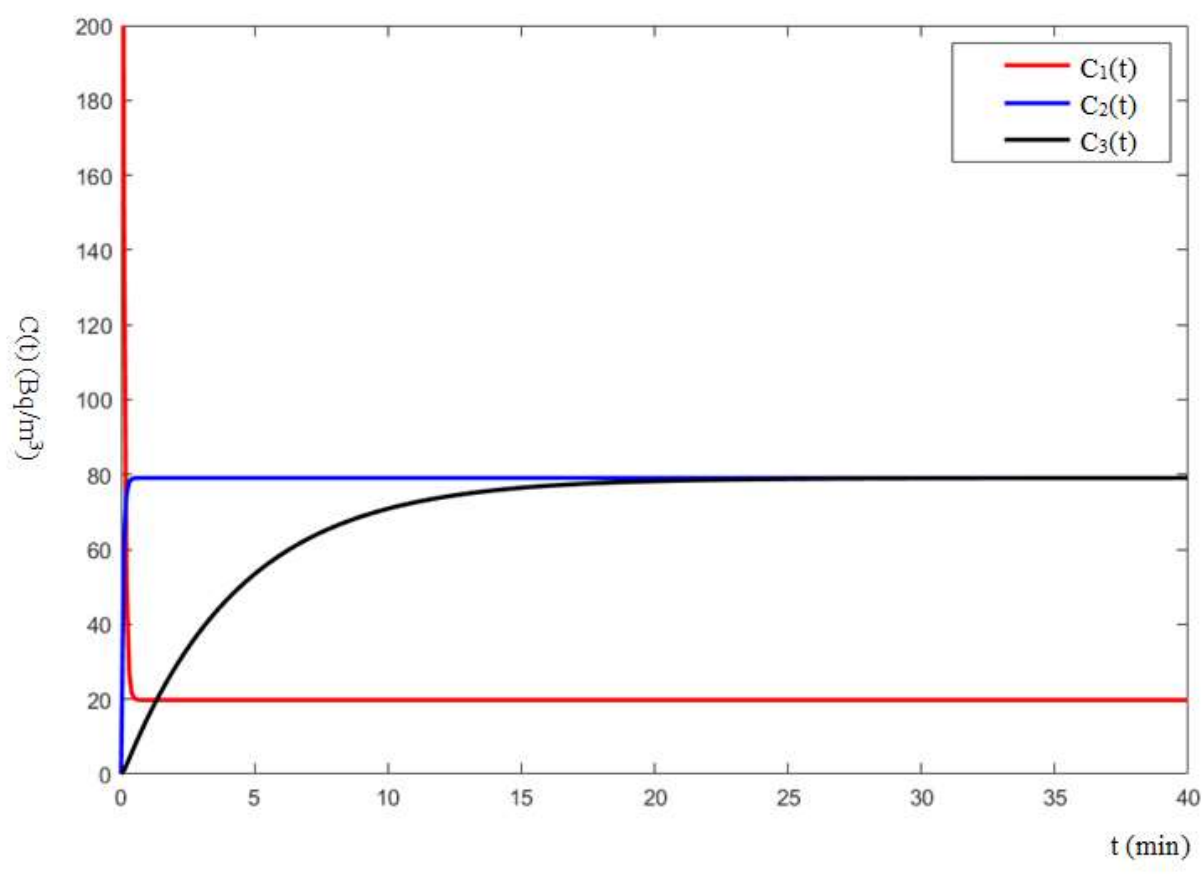
Fig. 2 Concentration change of $200 \mathrm{ml}$ water sample bottle 


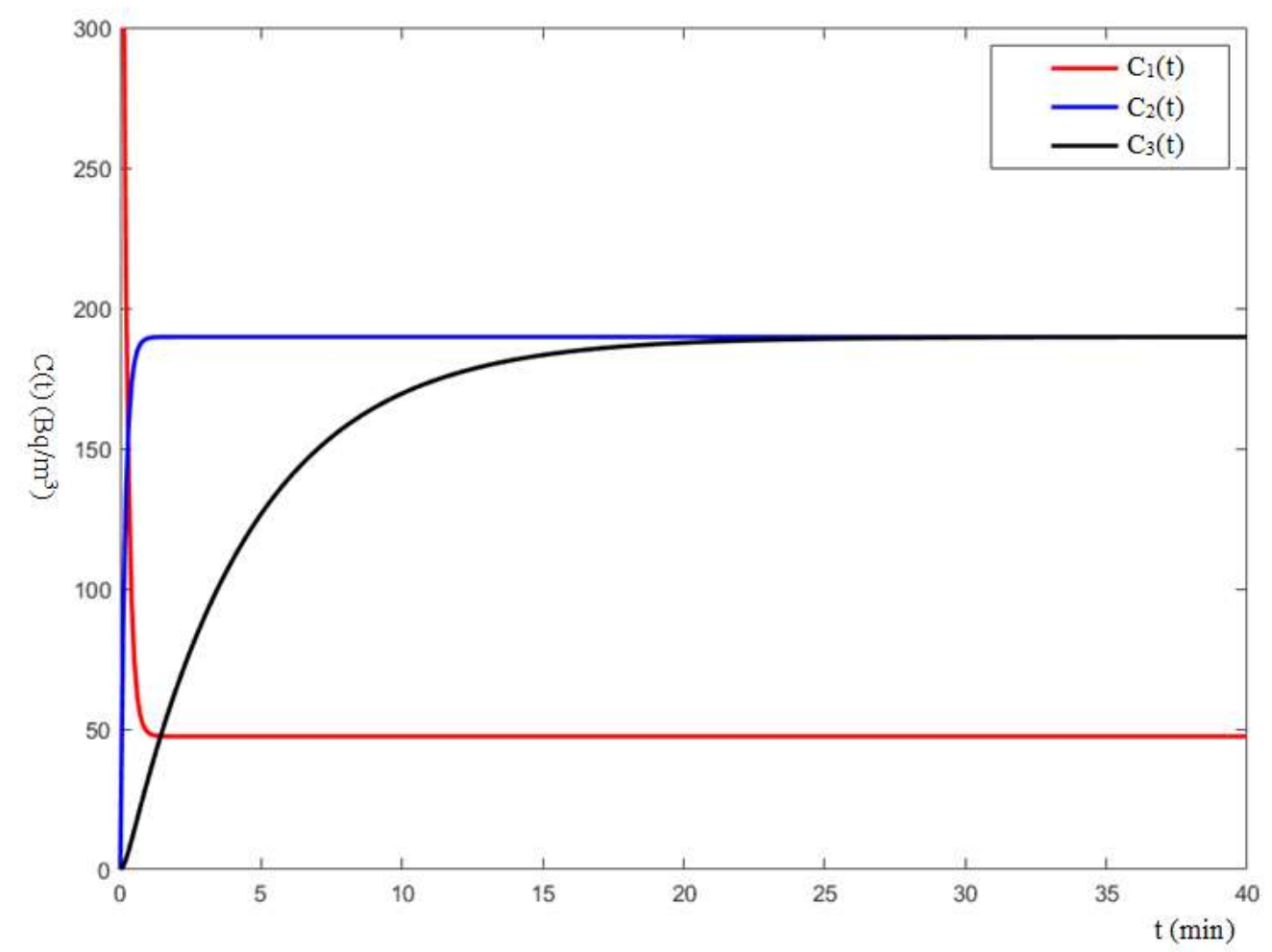

Fig. 3 Concentration change of $500 \mathrm{ml}$ water sample bottle

According the manual of Durridge Company, the conversion coefficients for the $250 \mathrm{ml}$ and $40 \mathrm{ml}$ water sample bottles are 4 and 25 respectively, the volume of the gas circuit is $0.88 \mathrm{~L}$, and $\frac{C_{a i r}(t)}{C_{w}(t)}=4$. Substituting the same parameters into equation (10), the $\mathrm{k}$ values are 4.15 and 24.47 respectively, which are approximately equal to the conversion coefficients 4 and 25 from the manual of Durridge Company.

\section{Conclusion}

The $\mathrm{H}_{2} \mathrm{O}$ accessory of Durridge Company based on the principle of bubbling method is wide used in the world for measuring radon concentration in water. However, there are only $40 \mathrm{ml}$ and $250 \mathrm{ml}$ water sample bottle, and the accessory is expensive. Moreover, the drying tube of the accessory is so small, which requires frequent replacement of the desiccant. A novel model is proposed to determine the concentration of radon in water by using any volume of sample bottle and drying tube, which will broaden the application of the device. Substituting the parameters of the $\mathrm{H}_{2} \mathrm{O}$ accessory of Durridge Company into the novel model, the conversion coefficient 
214 calculated by the novel model is similar to that from the manual of Durridge Company.

215 It means that the conversion coefficient obtained by the novel model is accurate and 216 reliable.

\section{Declarations}

219 Ethics approval and consent to participate Not applicable.

Consent for publication Not applicable.

Availability of data and materials All data generated or analyzed during this study are included in this published article.

Competing interests The authors declare that they have no competing interests

Funding Project supported by National Natural Science Foundation of China (Grant

No. U1865207), Natural Science Foundation of Hunan Province (Grant

No.2019JJ40002), Key Research and Development Program of Hunan Province

(Grant No. CX20191002), Hengyang Science and Technology Planning Project

Authors' contributions Conceptualization, methodology, and writing the original draft: $\mathrm{Tao} \mathrm{Hu}$ Yuan, Luwei Wang 
Axel Schmidt, Michael Schlueter, Martin Melles \& Michael Schubert. (2008). Continuous and discrete on-site detection of radon-222 in ground- and surface waters by means of an extraction module. Applied Radiation and Isotopes (12), https://doi.org/10.1016/j.apradiso.2008.05.005

D Lane-Smith. (2001). A continuous monitor for assessment of 222Rn in the coastal ocean. Journal of Radioanalytical and Nuclear Chemistry(1), https://doi.org/10.1023/A:1013217821419

Dimova Natasha, Burnett William C, Lane-Smith Derek. (2009). Improved automated analysis of radon $(222 \mathrm{Rn})$ and thoron $(220 \mathrm{Rn})$ in natural waters. Environmental science \& technology(22), https://doi.org/10.1021/es902045c

Eichler B, Zimmermann H P, Gäggeler H W. (2000). Adsorption of radon on ice surfaces. Journal of Physical Chemistry A, 104(14), https://doi.org/3126-3131. $\underline{10.1021 / \mathrm{jp} 9932158}$

GB5746-2006 (2006) Standards for drinking water quality of the People's Republic of China. China Standards Press, Beijing

H Dulaiova, R Peterson, WC Burnett, D Lane-Smith. (2005). A multi-detector continuous monitor for assessment of $222 \mathrm{Rn}$ in the coastal ocean. Journal of Radioanalytical and Nuclear Chemistry(2), https://doi.org/10.1007/s10967-005-0063-8

https://durridge.com/

Igarashi G, Saeki S, Takahata N, Sumikawa K, Tasaka S, Sasaki Y, Takahashi M, Sano Y. (1995). Ground-water radon anomaly before the kobe earthquake in Japan. Science. 269, 60-61. https://doi.org/10.1126/science.269.5220.60

ISO 13164-1, 2013. Water quality-Measurement of the activity concentration of radon-222-Part 1: General principles.

ISO 13164-2, 2013. Water quality-Measurement of the activity concentration of radon-222-Part 2: Gamma spectrometry method.

ISO 13164-3, 2013. Water quality-Measurement of the activity concentration of radon-222-Part 3: emanometric method.

ISO 13164-4, 2013. Water quality-Measurement of the activity concentration of radon-222-Part 4: Liquid scintillation counting method. 
Lee KY, Yoon YY, Cho SY, Lee E, Ko KS. (2014). An open loop equilibrator for continuous monitoring of radon at the groundwater-surface water interface. Journal of Radio analytical and Nuclear Chemistry, 304(1), 33-39. https://doi.org/10.1007/s10967-014-3502-6

Liu KK, Yui TF, Yeh YH, Tsai YB, Teng TL, (1984). Variations of radon content in groundwaters and possible correlation with seismic activities in northern Taiwan. Pure Appl Geophys PAGEOPH. 122, 231-244. https://doi.org/10.1007/BF00874596

Malik, Fi M, Rabaiee, N A, Jaafar, \& M S. (2015). Determination of radon concentration in water using $\mathrm{rad} 7 \mathrm{with}$ rad $\mathrm{h} 2 \mathrm{o}$ accessories. AIP Conference Proceedings. https://doi.org/10.1063/1.4915231

Pradeep Talwani, W S Moore \& Jin Chiang. (1980). Radon anomalies and microearthquakes at Lake Jocassee, South Carolina. (B6), https://doi.org/10.1029/JB085iB06p03079

Stieglitz Thomas C, Cook Peter G, Burnett William C. (2010). Inferring coastal processes from regional-scale mapping of 222Radon and salinity: examples from the Great Barrier Reef, Australia. Journal of environmental radioactivity(7), https://doi.org/10.1016/j.jenvrad.2009.11.012

Ta-Liang Teng. (1980). Some recent studies on groundwater radon content as an earthquake precursor. (B6), https://doi.org/10.1029/JB085iB06p03089

Tan Yanliang, Xiao Detao. (2011). A novel algorithm for quick and continuous tracing the change of radon concentration in environment.. The Review of scientific instruments(4), https://doi.org/10.1063/1.3572271

Tan Y, Xiao D. (2013). A novel method to measure the radon exhalation rate in only one measurement cycle. Analytical methods, 5. https://doi.org/10.1039/C2AY26134K

UNSCEAR (2000) United nation scientific committee on the effects of atomic radiation: sources, effects and risks of ionizing radiation. Report to the General Assembly, United Nations, New York.

USEPA (1991) National primary drinking water regulation; radionuclides: proposed rule. US Government Printing Office Federal Register 40 Parts 141 and 142 
Wang Yunxiang, Zhang Lei, Wang Jingbo \& Guo Qiuju. (2020). Study on an on-site radon-in-water measurement system based on degassing membrane. Radiation Measurements(C), https://doi.org/10.1016/j.radmeas.2019.106231

Weigel F. (1978). Radon. Chem. Ztg. 102, 287-299

Welch LE. (1994). An environmental chemistry experiment: the determination of radon levels in water. Akashdeep Publishing House. https://doi.org/10.1021/ed071p521

Yanliang Tan, Hongzhi Yuan, Kimberlee Kearfott.(2020).A model comparison of diffusion-controlled radon exhalation from solid and cavity walls with application to high background radiation areas. Environmental Science and Pollution Research (prepublish). https://doi.org/10.1007/s11356-020-10890-1

Yanliang Tan, Detao Xiao, Quan Tang, Jian Shan, Qingzhi Zhou, Bin Feng. (2015). Research on the perturbation phenomenon while tracing the radon concentration in real time. Stochastic Environmental Research and Risk Assessment(3). https://doi.org/10.1007/s00477-014-0900-9 